This document was prepared in conjunction with work accomplished under Contract No. DE-AC09-96SR18500 with the U. S. Department of Energy.

\title{
DISCLAIMER
}

This report was prepared as an account of work sponsored by an agency of the United States Government. Neither the United States Government nor any agency thereof, nor any of their employees, nor any of their contractors, subcontractors or their employees, makes any warranty, express or implied, or assumes any legal liability or responsibility for the accuracy, completeness, or any third party's use or the results of such use of any information, apparatus, product, or process disclosed, or represents that its use would not infringe privately owned rights. Reference herein to any specific commercial product, process, or service by trade name, trademark, manufacturer, or otherwise, does not necessarily constitute or imply its endorsement, recommendation, or favoring by the United States Government or any agency thereof or its contractors or subcontractors. The views and opinions of authors expressed herein do not necessarily state or reflect those of the United States Government or any agency thereof. 
WSRC-TR-2005-00046

Activity Estimates of Various Radionuclides in Saltstone Vapor Phase

M. Denham, Environmental Sciences and Technology

K. Crapse, Waste Processing Technology

January, 2005

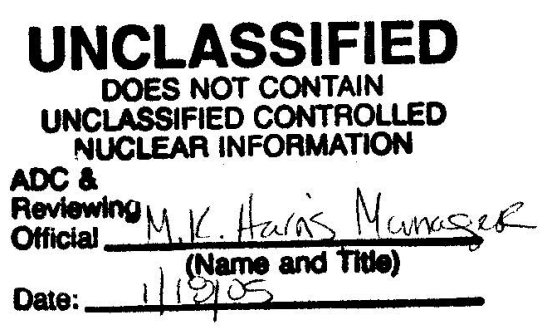


This page was intentionally left blank 


\section{Activity Estimates of Various Radionuclides in Saltstone Vapor Phase}

We were asked to estimate activities of various radionuclides in vapor phase associated with saltstone. Table 1 lists these radionuclides, as well as the estimated activity and concentration of each in the gas phase. Some of the activities are so low they should be considered zero. In particular, activity of the antimony and tin isotopes in the gas phase correspond to less than a molecule of gas per $340 \mathrm{~m}^{3}$ of vapor volume. Equilibrium calculations of the partitioning of each radionuclide between vapor and dissolved phases were done using The Geochemist's Workbench ${ }^{\circledR}$ (release 4.0).

Table 1: List of radionuclides, their calculated ratios of moles in gas to moles in aqueous phase, calculated activities and concentrations in gas phase.

\begin{tabular}{|c|c|c|c|}
\hline Constituent & $\frac{\text { Gas/Aqueous }}{\underline{\text { Ratio }^{1}}}$ & $\frac{\frac{\text { Activity in }}{\text { Gas Phase }}}{\underline{\text { (Ci) }}}$ & $\frac{\frac{\text { Concentration }}{\text { in Gas Phase }}}{\text { (Ci/Liter) }}$ \\
\hline C-14 & $3.4 \mathrm{E}-6$ & $3.4 \mathrm{E}-6$ & $1.0 \mathrm{E}-11$ \\
\hline $\mathrm{Cl}-36$ & $6.2 \mathrm{E}-18$ & $6.2 \mathrm{E}-8$ & $1.8 \mathrm{E}-23$ \\
\hline $\mathrm{H}-3$ & $2.5 \mathrm{E}-6$ & $2.5 \mathrm{E}-6$ & $7.4 \mathrm{E}-12$ \\
\hline I-129 & $5.9 E-16$ & $5.9 \mathrm{E}-16$ & $1.74 e-21$ \\
\hline $\mathrm{Sb}-125$ & $8.4 \mathrm{E}-43$ & $8.4 \mathrm{E}-43$ & $2.5 \mathrm{E}-48$ \\
\hline $\mathrm{Sb}-126$ & $8.4 \mathrm{E}-43$ & $8.4 E-43$ & $2.5 E-48$ \\
\hline Se-76 & $2.2 \mathrm{E}-8$ & $2.2 \mathrm{E}-8$ & $6.5 E-14$ \\
\hline $\mathrm{Sn}-121 \mathrm{~m}$ & $1.7 \mathrm{E}-64$ & $1.7 E-64$ & $5.0 \mathrm{E}-70$ \\
\hline Sn-126 & $1.7 \mathrm{E}-64$ & $1.7 E-64$ & $5.0 \mathrm{E}-70$ \\
\hline
\end{tabular}

The conceptual model used was that 1 curie of each constituent was available to partition between vapor and dissolved phases. The overall assumption is that exposure would come from a single release of the vapor phase from a saltstone vault. Assumed conditions within the saltstone are listed in Table 2.

\footnotetext{
${ }^{1}$ See memorandum text for explanation
} 
Table 2: Assumed properties of saltstone vaults.

\begin{tabular}{|l|c|c|}
\hline Property & Assumed value & Value used \\
\hline Vault dimensions (meters) & & \\
\hline Length & 180 & 180 \\
\hline \multicolumn{1}{|c|}{ Width } & 60 & 60 \\
\hline \multicolumn{1}{|c|}{ Depth } & 7.5 & 7.5 \\
\hline Total vault volume (m ${ }^{3}$ ) & 81000 & 81000 \\
\hline Saltstone porosity (fraction) & 0.42 & 0.42 \\
\hline Residual moisture (fraction) & 0.99 & 0.99 \\
\hline $\mathrm{pH}$ & 12 & 10 \\
\hline Eh (volts) & -0.2 to -0.4 & -0.2 to -0.4 \\
\hline $\mathrm{Na}^{-}$(moles/liter) & 6 & 0.01 \\
\hline $\mathrm{NO}_{3}$ - (moles/liter) & 6 & 0.01 \\
\hline
\end{tabular}

In the model used to simulate partitioning, a lower $\mathrm{pH}$ and lower ionic strength were used. $\mathrm{A} \mathrm{pH}$ of 10 is a more conservative case than a pH of 12 because most of the gases are less stable at high $\mathrm{pH}$. The lower ionic strength was used to assure reliability of the calculations. Ion association models such as those used in these calculations are unreliable at ionic strengths exceeding about 0.5 molal. Models are available for higher ionic strengths, but no parameters exist for I, Sb, Se, or Sn. Thus, a lower ionic strength was used. The implications of this are discussed in the Uncertainty section below.

Figure 1 shows a generalized flow diagram of steps used in the simulations. For a given constituent, these begin with choosing the gases to consider. The criteria for these choices were sufficiently high vapor pressures at $25^{\circ} \mathrm{C}$ and availability of thermodynamic data. It was assumed that absence of thermodynamic data is an indication that a gas is not common enough to warrant consideration. Thermodynamic data for most of the gases selected for consideration were then entered into the database to be used by The

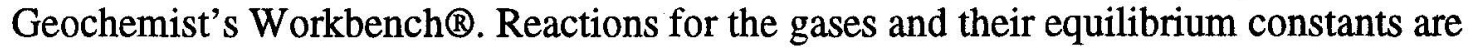
shown in Table 3. In 11 of 14 reactions acid is produced by degradation of the gas of interest, suggesting that most of the gas species are favored at lower $\mathrm{pH}$. Similar analyses were done to identify "worst case" scenarios for the master variables temperature, $\mathrm{pH}$,

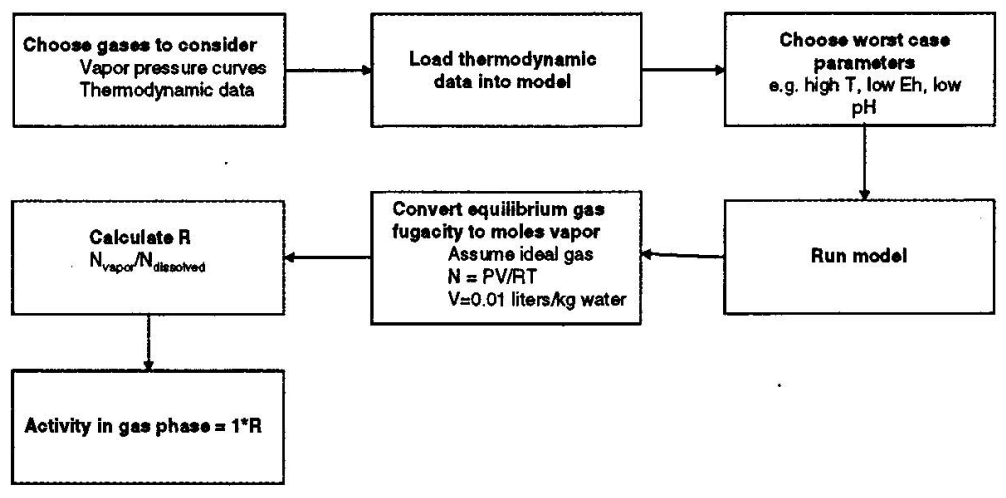

Figure 1: Flow diagram for gas/water partitioning calculations. 
and Eh by generating curves of gas fugacity versus the variable. An example is shown in Figure 2. The simulation was then run using parameters discussed below. From the model output (see Appendix 1 for an example), the moles of contaminant in the gas phase (assuming an ideal gas) and in the dissolved phase were calculated. It is assumed that there is 1 curie of each radionuclide in the total pore space of a vault. Thus, the ratio of activity in the gas phase to activity in the aqueous phase was multiplied by 1 curie to give the activities in the gas phase. These represent the activities in $340 \mathrm{~m}^{3}$ of vapor volume per vault.

Table 3: Contaminant gas species and reactions considered.

\begin{tabular}{|l|l|l|l|}
\hline Contaminant & $\begin{array}{c}\text { Gas } \\
\text { Species }\end{array}$ & Reaction & $\begin{array}{l}\text { Log K } \\
\left(\mathbf{2 5} \mathbf{5}^{\circ} \mathbf{C}\right)\end{array}$ \\
\hline $\mathrm{C}-14$ & $\mathrm{CO}_{2}$ & $\mathrm{CO}_{2(\mathrm{~g})}+\mathrm{H}_{2} \mathrm{O}=\mathrm{HCO}_{3}{ }^{-}+\mathrm{H}^{+}$ & -7.82 \\
\hline $\mathrm{Cl}-36$ & $\mathrm{Cl}_{2}$ & $\mathrm{Cl}_{2(\mathrm{~g})}+\mathrm{H}_{2} \mathrm{O}=2 \mathrm{Cl}^{-}+2 \mathrm{H}^{+}+1 / 2 \mathrm{O}_{2}$ & 3.03 \\
\hline $\mathrm{Cl}-36$ & $\mathrm{HClO}$ & $\mathrm{HClO}_{4(\mathrm{~g})}=\mathrm{Cl}^{-}+2 \mathrm{O}_{2}+\mathrm{H}^{+}$ & 33.38 \\
\hline $\mathrm{Cl}-36$ & $\mathrm{HCl}$ & $\mathrm{HCl}_{(\mathrm{g})}=\mathrm{Cl}^{-}+\mathrm{H}^{+}$ & 6.31 \\
\hline $\mathrm{H}-3$ & $\mathrm{H}_{2} \mathrm{O}$ & $\mathrm{H}_{2} \mathrm{O}_{(\mathrm{g})}=\mathrm{H}_{2} \mathrm{O}_{(\mathrm{g})}$ & 1.50 \\
\hline $\mathrm{I}-129$ & $\mathrm{I}_{2}$ & $\mathrm{I}_{2(\mathrm{~g})}+\mathrm{H}_{2} \mathrm{O}=2 \mathrm{I}+1 / 2 \mathrm{O}_{2}+2 \mathrm{H}^{+}$ & -21.53 \\
\hline $\mathrm{I}-129$ & $\mathrm{HI}$ & $\mathrm{HI}_{(\mathrm{g})}=\mathrm{I}+\mathrm{H}^{+}$ & 9.31 \\
\hline $\mathrm{Sb}-125,126$ & $\mathrm{SbCl}_{3}$ & $\mathrm{SbCl}_{3(\mathrm{~g})}+3 \mathrm{H}_{2} \mathrm{O}=\mathrm{Sb}(\mathrm{OH})_{3}{ }^{\circ}+3 \mathrm{Cl}^{-}+3 \mathrm{H}^{+}$ & 4.83 \\
\hline $\mathrm{Sb}-125,126$ & $\mathrm{SbCl}_{5}$ & $\mathrm{SbCl}_{5(\mathrm{~g})}+4 \mathrm{H}_{2} \mathrm{O}=\mathrm{Sb}(\mathrm{OH})_{3}{ }^{\circ}+5 \mathrm{Cl}^{-}+1 / 2 \mathrm{O}_{2}+5 \mathrm{H}^{+}$ & 2.74 \\
\hline $\mathrm{Sb}-125,126$ & $\mathrm{SbH}_{3}$ & $\mathrm{SbH}_{3(\mathrm{~g})}+3 / 2 \mathrm{O}_{2}=\mathrm{Sb}(\mathrm{OH})_{3}{ }^{\circ}$ & 143.11 \\
\hline $\mathrm{Se}-79$ & $\mathrm{H}_{2} \mathrm{Se}$ & $\mathrm{H}_{2} \mathrm{Se}_{(\mathrm{g})}+3 / 2 \mathrm{O}_{2}=\mathrm{SeO}_{3}{ }^{-2}+2 \mathrm{H}^{+}$ & 71.83 \\
\hline $\mathrm{Se}-79$ & $\mathrm{SeCl}_{4}$ & $\mathrm{SeCl}_{4(\mathrm{~g})}+3 \mathrm{H}_{2} \mathrm{O}=\mathrm{SeO}_{3}{ }^{-2}+4 \mathrm{Cl}^{-}+6 \mathrm{H}^{+}$ & 13.78 \\
\hline $\mathrm{Sn}-121 \mathrm{~m}, 126$ & $\mathrm{SnCl}_{4}$ & $\mathrm{SnCl}_{4(\mathrm{~g})}=\mathrm{Sn}^{+4}+4 \mathrm{Cl}^{-}$ & 15.85 \\
\hline $\mathrm{Sn}-121 \mathrm{~m}, 126$ & $\mathrm{SnH}_{4}$ & $\mathrm{SnH}_{4(\mathrm{~g})}+4 \mathrm{H}^{+}=4 \mathrm{H}_{2}+\mathrm{Sn}^{+4}$ & 20.10 \\
\hline
\end{tabular}




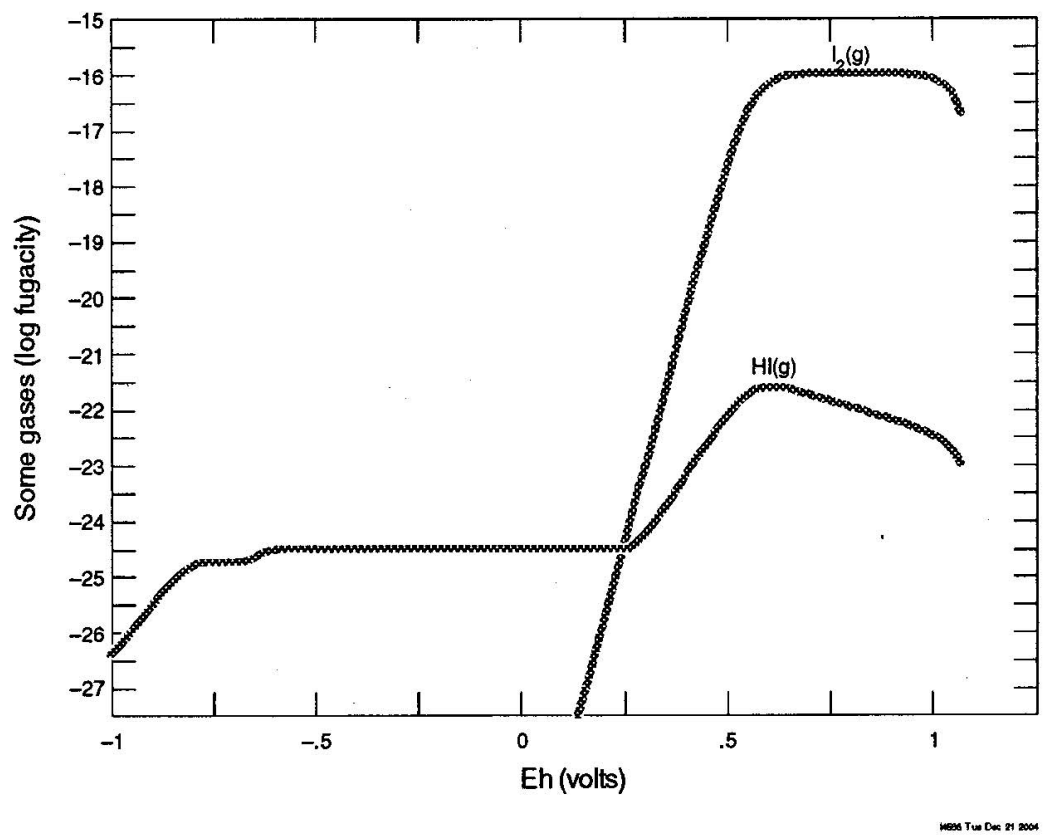

Figure 2: Curves used to indicate worst case Eh for modeling iodine gas generation.

The initial conditions for the simulations varied somewhat for different contaminants. For all contaminants it was assumed they were in a $0.01 \mathrm{~mole} / \mathrm{kg}$ solution of sodium nitrate. Table 4 shows concentrations of constituents of interest used for the models. The concentrations of tin, antimony, and selenium were set to $10 \mathrm{ug} / \mathrm{kg}_{\mathrm{H} 2 \mathrm{O}}$. These are much higher mass concentrations than calculated from $1 \mathrm{Ci}$ dissolved in a vault's pore fluid. This accounts for the stable isotopes of these elements that might be in the saltstone pore water. For I-129, a concentration of $1000 \mathrm{ug} / \mathrm{kg}_{\mathrm{H} 2 \mathrm{O}}$ was used to account for stable I-127 in the system. Bicarbonate and chloride for the $\mathrm{C}-14$ and $\mathrm{Cl}-36$ simulations were set at $100 \mathrm{mg} / \mathrm{kg}_{\mathrm{H} 2 \mathrm{O}}$. For the C-14 simulation the system was assumed to be closed to carbon dioxide. This is a worst case scenario because a system open to atmosphere would have very high concentrations of dissolved carbon dioxide at a $\mathrm{pH}$ of 10 . This would drive the ratio of $\mathrm{C}-14$ in gas to $\mathrm{C}-14$ in water to much lower values. For the tin and antimony simulations, a chloride concentration of $100 \mathrm{mg} / \mathrm{kg}_{\mathrm{H} 2 \mathrm{O}}$ was used to provide the chloride necessary for generation of tin and antimony chloride gases.

With the exception of the Se-79 simulation, systems were considered open to nitrogen gas at a fugacity of 0.7 (near atmospheric) and redox potentials were controlled by the $\mathrm{N}_{2} / \mathrm{NO}_{3}$ - couple. This is reasonable considering the high nitrate concentration in saltstone. However, it does result in a final redox potential that is higher than the Eh range expected for saltstone, 0.37 volts rather than -0.3 volts. This does not significantly affect any conclusions that may be drawn from this memorandum. In fact, it is conservative for $\mathrm{Cl}-36$, I-129, and the tin isotopes. For selenium, $\mathrm{H}_{2} \mathrm{Se}$ is the dominant 
gas, and thus, to simulate a worst case, redox potential was held constant at -0.4 volts and the system was closed with respect to $\mathrm{N}_{2}$ gas.

The calculated ratios of moles of contaminant in the gas phase to moles of contaminant in the aqueous phase are shown in Table 1 . The ratios were converted to activities by assuming that a total of 1 curie of each radionuclide was in the pore space of a saltstone vault. Concentrations were calculated using the volumes of vapor and water in the pore space, estimated from the dimensions of a vault, the porosity, and the residual moisture content.

Table 4: Concentrations of constituents used in simulations.

\begin{tabular}{|c|c|c|}
\hline Constituent & $\begin{array}{l}\text { Concentration } \\
\left.\text { (moles } / \mathrm{kg}_{\mathrm{H} 2 \mathrm{O}}\right)\end{array}$ & Comments \\
\hline $\mathrm{C}-14$ & $1.6 \mathrm{E}-3$ & {$\left[\mathrm{HCO}_{3}-\right]=100 \mathrm{mg} / \mathrm{kg}_{\mathrm{H} 2 \mathrm{O}}$} \\
\hline Cl-36 & $2.8 \mathrm{E}-3$ & \\
\hline $\mathrm{H}-3$ & - & \\
\hline I-129 & $7.9 \mathrm{E}-6$ & \\
\hline Sb-125, Sb-126 & $8.2 \mathrm{E}-8$ & {$[\mathrm{Cl}-]=2.8 \mathrm{E}-3 \mathrm{moles} / \mathrm{kg}_{\mathrm{H} 2 \mathrm{O}}$} \\
\hline Se-79 & $1.3 \mathrm{E}-7$ & Constant redox $\mathrm{Eh}=-0.4$ volts \\
\hline Sn-121m, Sn-126 & $8.4 \mathrm{E}-8$ & {$[\mathrm{Cl}-]=2.8 \mathrm{E}-3$ moles $/ \mathrm{kg}_{\mathrm{H} 2 \mathrm{O}}$} \\
\hline
\end{tabular}

\section{Uncertainty}

The primary uncertainty in these calculations is the use of lower ionic strengths in the modeling than those estimated for the saltstone pore fluids. This could lead to underestimation of the amount of a radionuclide in the gas phase for all constituents except tritium. For tritium, higher ionic strength lowers the vapor pressure of water at a given temperature, thus lowering the amount of tritium in the vapor phase. For other constituents, the high ionic strengths will likely result in higher activity coefficients than those at lower ionic strengths. As the activity coefficients increase the ratio of contaminant in the gas phase to contaminant in the aqueous phase will increase. This is illustrated by the reaction for $\mathrm{HI}_{(\mathrm{g})}$,

$$
\begin{aligned}
& \mathrm{HI}_{(\mathrm{g})}=\mathrm{H}^{+}+\mathrm{\Gamma} \\
& K=\frac{a_{H+} \times \gamma_{t_{-}} \times m_{l^{-}}}{f_{H I}}
\end{aligned}
$$

where $\mathrm{K}$ is the equilibrium constant, $\mathrm{a}_{\mathrm{H}+}$ is the activity of hydrogen ion, $\gamma_{\mathrm{I}}$ is the activity coefficient for the iodide ion, $\mathrm{m}_{\mathrm{I}}$ is the molality of the iodide ion, and $\mathrm{f}_{\mathrm{HI}}$ is the fugacity

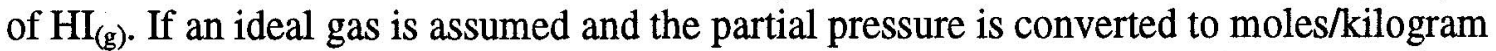
of gas $\left(\mathrm{m}_{\mathrm{HI}}\right)$, the of $\mathrm{m}_{\mathrm{I}}$ to $\mathrm{m}_{\mathrm{HI}}$ is the ratio of contaminant in the aqueous phase to that in the gas phase. The $\mathrm{a}_{\mathrm{H}+}$ is defined by the $\mathrm{pH}$ selected for the simulation. Thus, 


$$
\frac{K}{a_{H+}}=\frac{\gamma_{I-}}{R}
$$

where $\mathrm{R}$ is the ratio of contaminant in the gas phase to contaminant in the aqueous phase as reported in Table 4. Hence, as the activity coefficient of iodide increases R.must increase as well to maintain a constant value on the left side of the equation. However, it is unlikely that the activity coefficients will increase by any more than a factor of 10 . Such an increase would not significantly affect any conclusions based on this analysis. Furthermore, an increase in ionic strength would decrease the activity of water which will reduce the effect of increasing activity coefficients.

Uncertainty associated with the estimates in this memorandum could be minimized by performing sensitivity analyses of the results to variations in the major parameters. 


\section{Appendix 1}

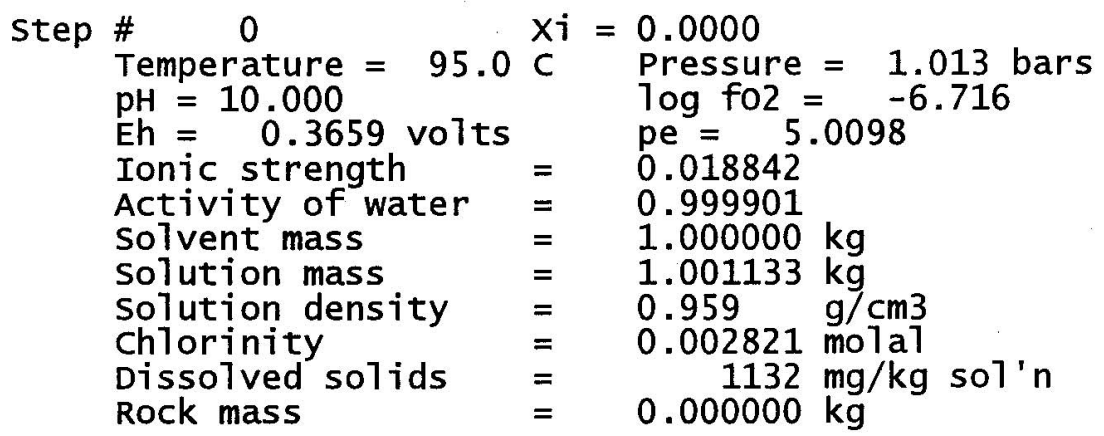

No minerals in system.

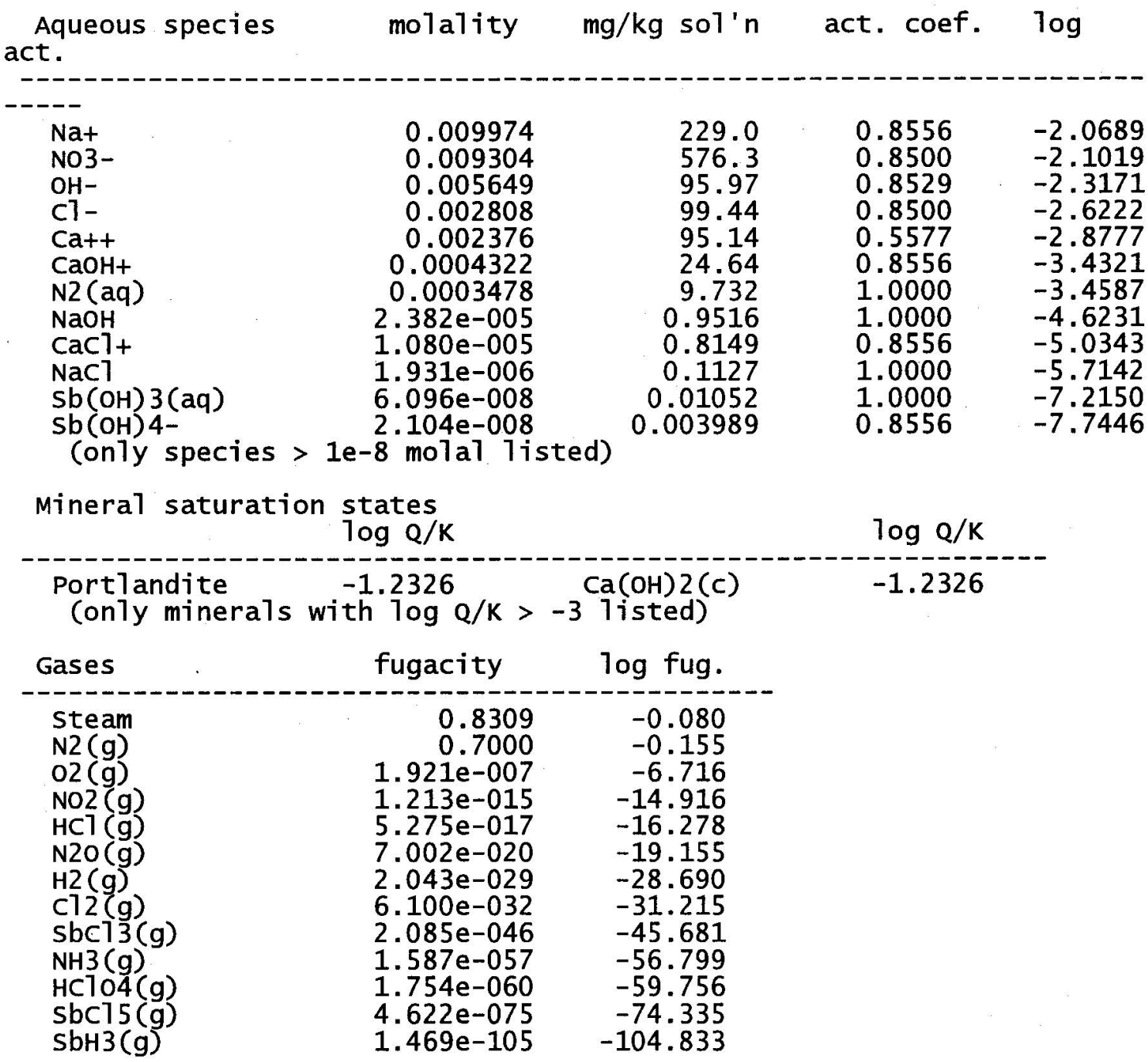


In fluid

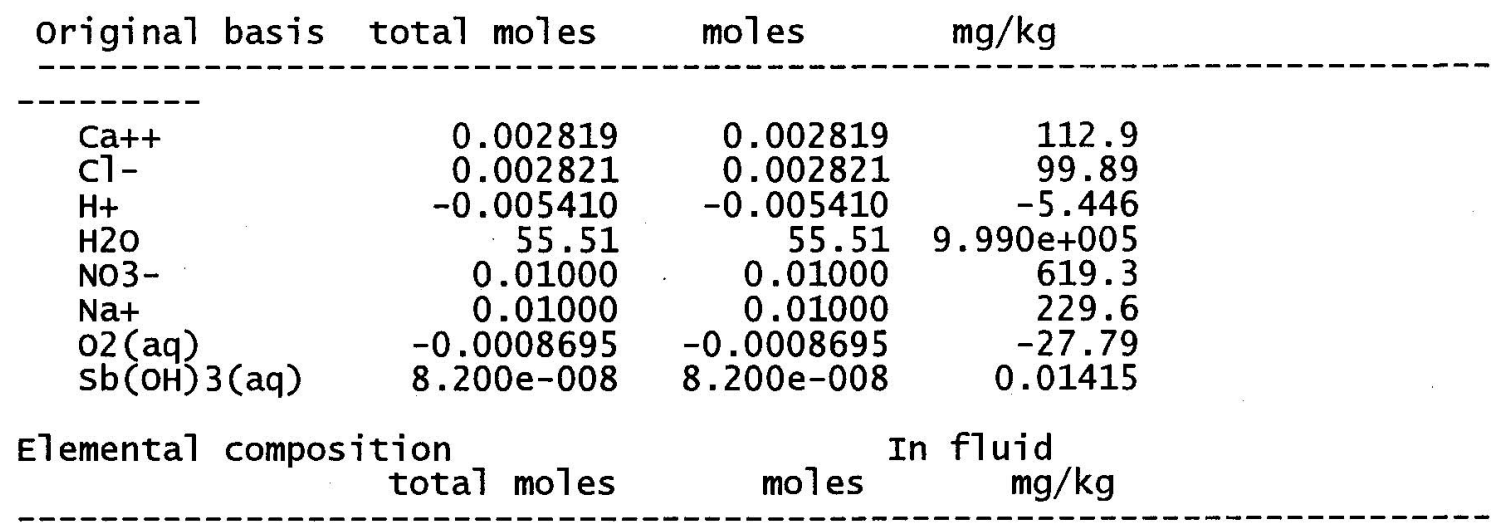

Antimony

Ca]cium

Chlorine

Hydrogen

Nitrogen

oxygen

Sodium
$8.200 e-008$
0.002819
0.002821
111.0
0.01000
55.54
0.01000

0.009972
112.9
99.89

$1.118 \mathrm{e}+005$

139.9

$8.876 \mathrm{e}+005$ 


\section{Appendix 2 \\ Design Check Instructions to Kim Crapse}

Specific instructions for this design check are as follows:

1) Check general technical approach.

2) Check calculations in the supporting spreadsheet.

3) Compare output generated for report using The Geochemist's Workbench to output generated using United States Geological Survey code PHREEQC.

\section{Design Check by Kim Crapse}

1) Check general technical approach.

The overall general approach is judged to be appropriate based on current assumptions regarding saltstone conditions and inventory. Uncertainties in the partitioning model are addressed and select sensitivity studies are described for several key parameters.

2) Check calculations in the supporting spreadsheet.

Checked calculations of fugacity to moles of gas in the vapor phase, $R$, and activities in the vapor and aqueous phases

3) Compare output generated for report using The Geochemist's Workbench to output generated using United States Geological Survey code PHREEQC.

Agreement between the output for the model output generated using The Geochemist's Workbench and PHREEQC provide a further validation of the approach. 